\title{
PROFIL KEMAMPUAN KOMUNIKASI MATEMATIKA TERTULIS SISWA MA DALAM MEMECAHKAN MASALAH PERMUTASI DITINJAU DARI PERBEDAAN GENDER
}

\author{
Ratna Dwi Lestari ${ }^{1}$, Suesthi Rahayuningsih ${ }^{2}$, Hari Joko Wiyono ${ }^{3}$ \\ Universitas Islam Majapahit, Jalan Raya Jabon Km 0.7 Mojokerto \\ ${ }^{1}$ ratna.dwi.lestari@gmail.com
}

\begin{abstract}
Abstrak
Penelitian ini bertujuan untuk mendeskripsikan profil kemampuan komunikasi matematika tertulis siswa MA laki-laki dan perempuan dalam memecahkan masalah permutasi. Penelitian ini dilaksanaan pada tahun ajaran 2016/2017 di MA Al- Mustofa Canggu, Mojokerto. Subjek penelitian terdiri dari 2 siswa kelas XI IPA yang meliputi 1 siswa perempuan dan 1 siswa laki-laki dengan mempertimbangkan perbedaan jenis kelamin, tingkah laku selama di sekolah dan mempunyai kemampuan matematika yang setara. Teknik pengumpulan data menggunakan triangulasi waktu dengan tes pemecahan masalah dan wawancara. Analisis data dilakukan dalam tiga tahap yaitu reduksi data, pemaparan data, dan penarikan kesimpulan. Hasil penelitian menunjukan bahwa terdapat perbedaan kemampuan komunikasi matematika tertulis siswa laki-laki dan siswa perempuan dalam memecahkan masalah permutasi. Perbedaan muncul pada aspek kelengkapan dalam tahap menyusun rencana penyelesaian. Sedangkan dalam aspek keakuratan dan kelancaran pada tahap memahami masalah, menyusun rencana penyelesaian, melaksanakan rencana penyelesaian dan meninjau kembali tidak terdapat perbedaan yang signifikan.
\end{abstract}

Kata Kunci : profil, kemampuan komunikasi matematika tertulis, pemecahan masalah, gender

\begin{abstract}
This study aimed to describe the profile of mathematics written communication skills MA students of men and women in solving the problem of permutations. This research is implemented in the academic year 2016/2017 in MA Al- Mustafa Canggu, Mojokerto. Subject of the study consisted of two students of class XI IPA covering first female students and one male student taking into account differences in gender, behavior while in school and have equal math abilities. Data collection techniques using triangulation troubleshooting time with tests and interviews. Data analysis was carried out in three stages: data reduction, exposure data, and drawing conclusions. The results showed that there are differences in the written mathematics communication ability of male students and female students in solving problems of permutations. The difference appears in the aspect of completeness in the stage of completion of the plan. Meanwhile, in the aspect of accuracy and fluency at the stage of understanding the problems, plan solutions, implementing and reviewing the settlement plan was not a significant difference
\end{abstract}

Keywords : profile, written mathematical communication skills, problem solving, gender

\section{Pendahuluan}

Komunikasi merupakan hal yang sangat penting pada semua segi kehidupan termasuk dunia pendidikan. Matematika sebagai alat komunikasi (mathematics is a connection) diperlukan oleh semua ilmu pengetahuan maupun dalam kehidupan sehari-hari (Haji, 2012:115). Kesadaran 
tentang pentingnya memperhatikan kemampuan siswa dalam berkomunikasi dengan menggunakan matematika yang dipelajari di sekolah perlu ditumbuhkan, sebab salah satu fungsi pelajaran matematika adalah cara mengomunikasikan gagasan secara praktis, sistematis dan efisien (Umar, 2012:3).

Menurut Permendiknas No.22 (Depdiknas, 2006) tentang standart isi, salah satu tujuan diberikan pelajaran matematika, adalah memahami konsep matematika, menjelaskan kerterkaitan antar konsep dan mengaplikasikan konsep atau algoritma, secara luwes, akurat, efisien, dan tepat, dalam pemecahan masalah. Untuk itu, dalam pembelajaran matematika hendaknya siswa diberikan latihan yang bersifat pemecahan masalah. Alasannya menurut Pehkonen (dalam Siswono, 2008:39) dengan pemecahan masalah dapat mengembangkan keterampilan kognitif siswa secara umum, dapat mendorong kreativitas siswa, pemecahan masalah merupakan bagian dari proses aplikasi matematika, dan pemecahan masalah memotivasi siswa untuk belajar matematika.

Menurut Veynisaicha (dalam Wardani, 2014:101) pemecahan masalah adalah suatu proses untuk mengatasi kesulitan yang dihadapi untuk mencapai suatu tujuan yang hendak dicapai. Oleh karena itu, masalah yang diberikan belum tampak jelas maka diperlukan strategi pemecahan masalah yang tepat. Pemecahan masalah memiliki strategi dan langkah-langkah dalam penyelesaiannya. Polya (1957) menyusun prosedur memecahkan masalah dalam empat langkah, yaitu: (1) memahami masalah (understanding problem). (2) membuat rencana penyelesaian (devising a plan. (3) melaksanakan rencana penyelesaian (carrying out the plan). (4) meninjau kembali (looking back).

Kemampuan siswa dalam memecahkan masalah dipengaruhi oleh pengalamanpengalaman mereka terhadap matematika dan juga kemampuan dasar matematikanya (Sugiarto, 2014:2). Secara psikologis siswa laki-laki dan perempuan berbeda, faktor psikologis terkait dengan perhatian, minat, bakat, motivasi, kematangan, dan kesiapan dalam belajar. Menurut Halpern (dalam Arends, 2013:81) menyatakan bahwa anak perempuan lebih sukses dalam seni bahasa, pemahaman membaca, dan komunikasi tulis dan lisan, sementara anak laki-laki tampaknya sedikit lebih unggul dalam ilmu matematika dan pemikiran matematis. Perbedaanperbedaan antara anak laki-laki dan perempuan muncul karena perbedaan-perbedaan yang ada dalam otaknya Gurian (dalam Arends, 2013:81). Secara umum perbedaan gender dalam prestasi belajar matematika tergantung pada isi tugas, sifat pengetahuan dan keterampilan yang ditugaskan serta kondisi saat mengerjakan tugas Goos (dalam Prayitno, 2013:3). 
Berdasarkan latar belakang tersebut, maka tujuan yang ingin dicapai dalam penelitian ini adalah mendeskripsikan profil kemampuan komunikasi matematika tertulis siswa MA laki-laki dalam memecahkan masalah permutasi dan mendeskripsikan profil kemampuan komunikasi matematika tertulis siswa MA perempuan dalam memecahkan masalah permutasi.

\section{Metode Penelitian}

Sesuai dengan permasalahan yang diteliti maka jenis penelitian ini adalah deskriptif kualitatif. Penelitian ini bertujuan untuk mendiskripsikan kemampuan komunikasi matematika tertulis siswa dalam pemecahan masalah permutasi ditinjau dari perbedaan gender. Hal yang dikaji dalam penelitian ini yaitu profil kemampuan komunikasi matematika tertulis siswa MA dalam memecahkan masalah permutasi ditinjau dari perbedaan gender. Subjek dalam penelitian ini adalah satu siswa perempuan dan satu siswa laki-laki Kelas XI MA AL-Mustofa Canggu yang komunikatif dan memiliki kemampuan matematika yang setara. Subjek dipilih dengan mempertimbangkan perbedaan jenis kelamin antara siswa laki-laki dan perempuan dan tingkah laku selama disekolah.

Instrumen dalam penelitian ini merupakan alat yang digunakan untuk mengambil data. Instrumen dalam penelitian ini yaitu sebagai berikut :

a. Lembar tes kemampuan memecahkan masalah yaitu berupa satu soal esay permutasi yang dijadikan pedoman dan dasar dalam mendiskripsikan profil kemampuan komunikasi matematika tertulis siswa dalam memecahkan masalah ditinjau dari perbedaan gender.

b. Pedoman wawancara. Wawancara ini dilakukan untuk mendukung data yang diperoleh dari hasil tes pemecahan masalah. Jenis wawancara yang digunakan peneliti adalah wawancara semi terstruktur.

Teknik pengumpulan data yang digunakan dalam penelitian ini yaitu dengan metode tes dan wawancara. Metode tes memecahkan masalah digunakan untuk mengumpulkan data penelitian tentang kemampuan memecahkan masalah siswa ketika menyelesaikan soal permutasi. Selanjutnya melalui wawancara digunakan untuk menggali pemikiran siswa ketika menyelesaikan tes pemecahan masalah dan untuk mengetahui hal-hal yang menjadi alasan kenapa siswa memberikan jawaban seperti itu selain itu untuk mendeskripsikan profil kemampuan komunikasi matematika tertulis siswa. Untuk menentukan validitas data digunakan triangulasi waktu yaitu membandingkan dan mengecek balik derajat kepercayaan informasi yang diperoleh melalui waktu yang berbeda. Validasi data dilakukan dengan membandingkan data yang diperoleh dari hasil pengambilan pertama dan data hasil pengambilan kedua. Jadi data yang diperoleh dari TPM (Tes Memecahkan Masalah) 1 dibandingkan dengan data yang diperoleh 
dari TPM 2. Data dikatakan valid jika ada konsistensi informasi yang diberikan dari data hasil pengambilan pertama dan kedua.

Tahap analisis data dalam penelitian ini meliputi tahap-tahap sebagai berikut:

1. Teknik analisis data hasil tes memecahkan masalah

Analisis terhadap kebenaran jawaban subjek penelitian pada saat mengerjakan tes tulis memecahan masalah siswa yang didasarkan pada kunci alternatif jawaban yang mengacu pada indikator kemampuan komunikasi matematika tentang keakuratan, kelengkapan dan kelancaran dan indikator pemecahan masalah Polya (1957) yang meliputi memahami masalah (understand the problem), menyusun rencana (devising a plan), melaksanakan rencana (carry out the plan), meninjau kembali (looking back).

2. Teknik analisis data hasil wawancara

Hasil wawancara digunakan untuk memperkuat hasil dari tes tulis. Selanjutnya data hasil wawancara tersebut dianalisis dengan langkah sebagai berikut : (1) Reduksi data dengan memilih hal-hal yang pokok, dan memfokuskan pada hal-hal yang penting, (2) Memaparkan hasil reduksi dalam bentuk uraian, (3) Menarik kesimpulan.

\section{Hasil dan Pembahasan}

Berdasarkan dari hasil dan analisis, maka berikut profil kemampuan komunikasi matematika tertulis Siswa MA dalam memecahkan masalah permutasi

Kemampuan Komunikasi Matematika Tertulis Subjek Laki-Laki, pada aspek keakuratan pada indikator memahami masalah subjek mampu mengidentifikasi hal-hal yang diketahui dan ditanya dengan benar. Pada tahap membuat rencana penyelesaian mampu menuliskan gambar/sketsa sebagian cara duduk siswa beserta keterangannya sesuai dengan hal-hal yang diketahui dan ditanya dengan benar yang diminta pada soal beserta keterangannya sesuai dengan hal-hal yang diketahui dan ditanya dengan benar dan lengkap, selain itu juga menuliskan rumus/syarat dengan benar menurut kaidah matematika, pada tahap melaksanakan rencana penyelesaian mampu melakukan perhitungan dengan menggunakan rumus secara benar, selanjutnya pada tahap meninjau kembali subjek menuliskan kesimpulan dengan benar dan subjek mampu menjelaskan kesimpulan dari permasalahan secara akurat. Pada aspek kelengkapan pada indikator memahami masalah subjek mampu mengidentifikasi hal-hal yang diketahui dan ditanya dengan benar. Pada tahap membuat rencana penyelesaian subjek kurang lengkap dalam membuat gambar/sketsa yang diminta pada soal beserta keterangannya sesuai dengan hal-hal yang diketahui dan ditanya, tetapi subjek mampu menuliskan rumus/syarat dengan benar menurut kaidah matematika, pada tahap melaksanakan rencana penyelesaian 
mampu melakukan perhitungan permutasi siklis dengan menggunakan rumus secara benar, selanjutnya pada tahap meninjau kembali subjek menuliskan kesimpulan dengan benar dan subjek mampu menjelaskan kesimpulan dari permasalahan secara lengkap. Dan pada aspek kelancaran pada indikator memahami masalah subjek mampu mengidentifikasi hal-hal yang diketahui dan ditanya dengan lancar. Pada tahap membuat rencana penyelesaian mampu menuliskan gambar/sketsa yang diminta pada soal beserta keterangannya sesuai dengan hal-hal yang diketahui dan ditanya dengan lancar, selain itu juga menuliskan rumus/syarat dengan benar dan lancar menurut kaidah matematika, pada tahap melaksanakan rencana penyelesaian mampu melakukan perhitungan permutasi siklis dengan menggunakan rumus secara benar, selanjutnya pada tahap meninjau kembali subjek menuliskan kesimpulan dengan benar dan mampu menjelaskan kesimpulan dari permasalahan secara lancar.

Kemampuan Komunikasi Matematika Tertulis Subjek Perempuan, pada aspek keakuratan pada indikator memahami masalah subjek mampu mengidentifikasi hal-hal yang diketahui dan ditanya dengan benar. Pada tahap membuat rencana penyelesaian mampu menuliskan gambar/sketsa yang diminta pada soal beserta keterangannya sesuai dengan hal-hal yang diketahui dan ditanya dengan benar dan lengkap, selain itu juga menuliskan rumus/syarat dengan benar menurut kaidah matematika, pada tahap melaksanakan rencana penyelesaian mampu melakukan perhitungan dengan menggunakan rumus secara benar, selanjutnya pada tahap meninjau kembali subjek menuliskan kesimpulan dengan benar dan subjek mampu menjelaskan kesimpulan dari permasalahan secara akurat. Pada aspek kelengkapan pada indikator memahami masalah subjek mampu mengidentifikasi hal-hal yang diketahui dan ditanya dengan benar. Pada tahap membuat rencana penyelesaian mampu menuliskan gambar/sketsa yang diminta pada soal beserta keterangannya sesuai dengan hal-hal yang diketahui dan ditanya dengan benar dan lengkap, selain itu juga menuliskan rumus/syarat dengan benar menurut kaidah matematika, pada tahap melaksanakan rencana penyelesaian mampu melakukan perhitungan permutasi siklis dengan menggunakan rumus secara benar, selanjutnya pada tahap meninjau kembali subjek menuliskan kesimpulan dengan benar dan subjek mampu menjelaskan kesimpulan dari permasalahan secara lengkap. Dan pada aspek kelancaran pada indikator memahami masalah subjek mampu mengidentifikasi hal-hal yang diketahui dan ditanya dengan lancar. Pada tahap membuat rencana penyelesaian mampu menuliskan gambar/sketsa yang diminta pada soal beserta keterangannya sesuai dengan hal-hal yang diketahui dan ditanya dengan lancar, selain itu juga menuliskan rumus/syarat dengan benar dan lancar menurut kaidah matematika, pada tahap melaksanakan rencana penyelesaian mampu melakukan perhitungan permutasi siklis 
dengan menggunakan rumus secara benar dan lancar sesuai dengan alur yang digambarnya meskipun sempat ragu-ragu dalam membuat gambar dan menuliskan hasilnya. Selanjutnya pada tahap meninjau kembali subjek menuliskan kesimpulan dengan benar dan mampu menjelaskan kesimpulan dari permasalahan secara lancar.

Pada penelitian ini subjek perempuan mampu memenuhi semua indikator kemampuan komunikasi matematika tertulis sedangkan subjek laki-laki belum mampu memenuhi satu indikator yaitu dalam tahap membuat rencana penyelesaian masalah subjek laki-laki tidak lengkap dalam membuat gambar/sketsa. Dengan demikian kemampuan komunikasi matematika tertulis siswa perempuan sedikit lebih unggul daripada siswa laki-laki. Namun, perbedaan kemampuan komunikasi matematika tertulis antara subjek perempuan dan subjek laki-laki dalam penelitian ini tidak terlalu besar. Berbeda dengan hasil penelitian sebelumnya yang dilakukan oleh Izwita Dewi (2014) Peneliti menyimpulkan bahwa subjek laki-laki memiliki kemampuan komunikasi matematika lebih tinggi. Serta menurut Diane Helpern (dalam Arends, 2013:87) bahwa anak perempuan lebih sukses dalam seni bahasa, pemahaman membaca, dan komunikasi tulis dan lisan, sementara anak laki-laki tampaknya sedikit lebih unggul dalam ilmu matematika dan pemikiran matematis.

Sehingga dalam hal ini tidak ada peran gender yang saling mengungguli dalam matematika sesuai dengan pendapat dari Zhixia (dalam Arkham, 2014:30) bahwa tidak ada peran gender, laki-laki atau perempuan saling mengungguli dalam matematika bahwa perempuan bisa lebih unggul dalam bidang yang berkaitan dengan matematika. Menurut American psychological assosiation in sciene daily (dalam Arkham, 2014:30) dikemukakan bahwa berdasarkan analisis terbaru dari penelitian international kemampuan perempuan diseluruh dunia dalam matematika tidak lebih buruk daripada kemampuan laki-laki meskipun laki-laki memiliki kepercayaan diri yang lebih dari perempuan dalam matematika, dan perempuan-perempuan dari negara dimana kesamaan gender telah diakui menunjukkan kemampuan yang lebih baik dalam tes matematika.

Dalam penelitian ini hal yang perlu didiskusikan hasil dari penelitian ini adalah kemampuan komunikasi matematika siswa perempuan sedikit lebih unggul daripada siswa lakilaki. Namun, perbedaan kemampuan komunikasi matematika antara subjek laki-laki dan subjek perempuan dalam penelitian ini tidak terlalu besar. Penelitian ini sesuai dengan pendapat Zhixia (dalam Arkham, 2014:30) bahwa tidak ada peran gender, laki-laki atau perempuan saling mengungguli dalam matematika bahwa perempuan bisa lebih unggul dalam bidang yang berkaitan dengan matematika. Menurut American psychological assosiation in sciene daily (dalam Arkham, 2014:30) dikemukakan bahwa berdasarkan analisis terbaru dari penelitian 
international kemampuan diseluruh dunia dalam matematika tidak lebih buruk daripada kemampuan laki-laki meskipun laki-laki memiliki kepercayaan diri yang lebih dari perempuan dalam matematika, dan perempuan-perempuan dari negara dimana kesamaan gender telah diakui menunjukkan kemampuan yang lebih baik dalam tes matematika. Namun, dalam penelitian sebelumnya yang dilakukan Dewi (2014) dalam penelitiannya mendeskripsikan bahwa komunikasi matematis laki-laki yang memiliki kemampuan matematika tinggi lebih akurat daripada mahasiswa perempuan yang mempunyai kemampuan matematika tinggi. Tetapi dalam penelitian ini subjek perempuan lebih unggul daripada subjek laki-laki.

\section{Simpulan dan Saran}

Profil kemampuan komunikasi matematika tertulis Siswa MA dalam memecahkan masalah permutasi, subjek laki-laki dalam memecahkan masalah permutasi dari aspek kemampuan komunikasi matematika tertulis yaitu keakuratan, kelengkapan, dan kelancaran kemampuan komunikasi matematika tertulis siswa dalam memecahkan masalah permutasi adalah akurat, tetapi dalam indikator kelengkapan ada satu indikator yang tidak bisa terpenuhi, tetapi subjek dapat memecahkan masalah dengan lancar. Sedangkan subjek perempuan dalam memecahkan masalah permutasi dari aspek kemampuan komunikasi matematika tertulis yaitu keakuratan, kelengkapan, dan kelancaran kemampuan komunikasi matematika tertulis siswa dalam memecahkan masalah permutasi adalah akurat, lengkap dan lancar.

Dari hasil penelitian ini diharapkan ada penelitian lanjutan yang menggunakan penelitian kemampuan komunikasi matematika tertulis dan lisan agar diperoleh hasil yang maksimal dan bisa memberikan banyak kontribusi terhadap pendidikan

\section{Referensi}

Arends, Richard I. 2013. Belajar Untuk Mengajar (Learning To Teach). Jakarta: Salemba Humanika.

Arkham, Hanni Pratiwi. 2014. Penalaran Adaptif Siswa Dalam Menyelesaikan Soal Cerita Matematika Materi Bangun Ruang Di Smp Negeri 4 Surabaya Berdasarkan Perbedaan Gender. Skripsi tidak diterbitkan. Surabaya: Universitas Islam Negeri Sunan Ampel Surabaya.

Depdiknas. 2006. Permendiknas No. 22 tahun 2006. Badan Standar Nasional Pendidikan. Jakarta.

Dewi, Izwita. 2014. Profil Keakuratan Komunikasi Matematis Mahasiswa Calon Guru Ditinjau dari Perbedaan Jender. Jurnal Didaktik Matematika Jurusan Matematika Universitas Negeri Medan.ISSN: 2355-4185, Vol. 1. No. 2 September 2014, hal 1-12. 
Haji, Saleh. 2012. Pengaruh Pembelajaran Kontekstual Terhadap Kemampuan Komunikasi Matematika Siswa SMP Kota Bengkulu. Jurnal Exacta Jurusan Pendidikan MIPA FKIP Universitas Bengkulu . ISSN 1412-3617, Vol. X. No. 2 Desember 2012, hal 115.

Polya, G .1957. How to Solve it. A New Aspect of Mathematical Method. New Jersey: Princeton University Press.

Prayitno, Sudi dkk. 2013. Komunikasi Matematis Siswa SMP Dalam Menyelesaikan Soal Matematika Berjenjang Ditinjau Dari Perbedaan Gender. Makalah dipresentasikan dalam Seminar Nasional Matematika dan Pendidikan Matematika dengan tema " Penguatan Peran Matematika dan Pendidikan Matematika untuk Indonesia yang Lebih Baik". Jurusan Pendidikan Matematika FMIPA Universitas Negeri Yogyakarta. 9 November.

Siswono, Tatag Y.E.2008. Model Pembelajaran Matematika Berbasis Pengajuan dan Pemecahan Masalah Untuk Meningkatkan Kemampuan Berpikir Kreatif. Surabaya: Unesa University Press.

Sugiyono. 2013. Metode Penelitian Kuantitatif, Kualitatif dan R\&D. Bandung: Alfabeta.

Sugiarto, Hendrik \& Mega Teguh Budiarto. 2014. Kemampuan Komunikasi Matematika Siswa Smp Dalam Pemecahan Masalah Ditinjau Dari Kemampuan Matematika. Jurnal Ilmiah Pendidikan Matematika, FMIPA Universitas Negeri Surabaya. Volume 3 No. 3 Tahun 2014, hal 1-5.

Umar, Wahid. 2012. Membangun Kemampuan Komunikasi Matematis Dalam Pembelajaran Matematika. Jurnal Ilmiah Program Studi Matematika STKIP Siliwangi Bandung. ISSN 2089-6867, Vol 1. No.1 Februari 2012, hal 1-9.

Wardani, Azisah Kurnia. 2014. Kemampuan Pemecahan Masalah Berdasarkan Perbedaan Jenis Kelamin. Jurnal Pendidikan Matematika STKIP PGRI Sidoarjo. ISSN: 2337-8166, Vol. 2 No.1, Maret 2014, hal 99-108. 